\title{
THE EFFECT OF DECELLULARIZATION TECHNIQUE ON COLLAGEN TYPE II AND MATRICES POROSITY OF CARTILAGE BOVINE SCAFFOLD
}

\author{
Dwikora Novembri Utomo ${ }^{*}$, Ika Benny Kartika Sari ${ }^{2}$ \\ ${ }^{1}$ Senior Consultant of Orthopaedic and Traumatology Department, Faculty of Medicine, \\ Universitas Airlangga, Dr Soetomo General Hospital, Surabaya \\ ${ }^{2}$ Resident of Orthopaedic and Traumatology Department, Faculty of Medicine, Universitas \\ Airlangga, Dr Soetomo General Hospital, Surabaya \\ *Corresponding Author: Dwikora Novembri Utomo, Senior Consultant of Orthopedic and \\ Traumatology Department, Faculty of Medicine, Universitas Airlangga, Jl. Mayjen Prof. Dr. \\ Moestopo 6-8, Surabaya \\ E-mail: dwikora_utomo@yahoo.com
}

\begin{abstract}
ABSTRAK
Latar Belakang: Tulang rawan sendi orang dewasa memiliki kemampuan perbaikan jaringan yang terbatas apabila terjadi kerusakan. Rekayasa jaringan berbasis stem sel telah menjadi alternatif terapi untuk pengobatan kerusakan tulang rawan sendi. Penggunaan cartilage bovine yang mengalami deselularisasi dapat berfungsi sebagai scaffold untuk mendukung proliferasi dan diferensiasi stem sel.
\end{abstract}

Tujuan: Penelitian ini membandingkan pengaruh teknik deselularisasi terhadap kadar kolagen tipe II dan porositas matriks cartilage bovine scaffold.

Metode: Penelitian laboratoris eksperimental ini menggunakan scaffold tulang rawan bovine yang dilakukan deselularisasi menggunakan teknik physical, kimiawi, dan enzimatik dengan variasi waktu dan konsentrasi yang berbeda-beda, kemudian dilakukan pengukuran konsentrasi kolagen tipe II dengan metode imunohistokimia dan evaluasi ukuran porositas dengan mikroskop elektron.

Hasil: Pada preparat dengan konsentrasi tertinggi dan waktu perendaman terlama yakni SDS $5 \%$ adalah selama 72 jam, proses deselularisasi terjadi secara sempurna. Didapatkan kandungan kolagen tipe II dengan konsentrasi yang signifikan lebih tinggi dibandingkan kontrol dan preparat lainnya, serta memiliki porositas yang saling berhubungan dalam ukuran besar.

Kesimpulan: Konsentrasi kolagen tipe II yang tinggi dan diameter porus yang besar setelah proses deselularisasi pada cartilage bovine scaffold menegaskan bahwa scaffold ini masih memiliki biochemical cues yang cukup optimal sehingga dapat menjadi kerangka mekanik dan lingkunan stem sel yang baik dalam upaya memperbaiki kerusakan tulang rawan. Diharapkan hasil ini menjadi standar baku pembuatan deselularisasi cartilage bovine scaffold. Kata kunci: Tulang rawan sendi, cartilage bovine scaffold, deselularisasi

\begin{abstract}
Background: Cartilage has limited capacity for self-repair in case of defect. Stem cell based tissue engineering has become an alternative therapy for the treatment of cartilage defect. The use of decellularized cartilage bovine can serve as scaffold to support proliferation dan differentiation of the stem cell.

Purpose: This research is to compare the effect of decellularization technique on collagen type II and matrices porosity of cartilage bovine scaffold.

Methods: This experimental laboratory research used cartilage bovine scaffold which was decellularized using physical, chemical and enzymatic techniques with different time and concentration variations, then collagen type II measurement was performed by immunohistochemical method and evaluation of porosity size with electron microscopy.
\end{abstract}


Results: In the preparations with the highest concentration and the longest immersion time of 5\% SDS for 72 hours, the decellularization process occurs perfectly. The collagen type II content was found to have significantly higher concentrations than the controls and other preparations, and have interconnected porosities in large size.

Conclusion: High concentrations of collagen type II and large diameter of porus after decellularization process in cartilage bovine scaffold confirm that this scaffold still has optimum biochemical cues that can be a good mechanical framework and microenvironment stem cell in effort to repair the cartilage defects. This result was expected to become a standard for the deselularization making of cartilage bovine scaffold.

Keywords: cartilage joint, cartilage bovine scaffold, decellularization

\section{PENDAHULUAN}

Tulang rawan sendi orang dewasa memiliki kemampuan perbaikan jaringan yang terbatas apabila terjadi kerusakan. Pada awalnya, akan terjadi peningkatan aktivitas mitosis dan sintesis matriks oleh kondrosit untuk menutup defek, dan akan berlanjut dengan menyisakan jaringan fibrocartilage.

Angka kejadian osteoarthritis di Indonesia sangat tinggi, yaitu sekitar 5\% pada usia <40th, $30 \%$ pada usia 40-60 tahun dan $65 \%$ pada usia $>61$ tahun. $^{2}$

Mesenchymal stem cell merupakan sel induk yang bersifat multipotensial, apabila berada dalam scaffold yang mendukung, disertai dengan signaling biokimia, akan menghasilkan diferensiasi stem sel yang baik untuk mengganti jaringan tulang rawan yang rusak baik yang disebabkan oleh trauma maupun penyakit degeneratif dengan suatu jaringan hyaline-like cartilage. ${ }^{3}$
Teknik pembuatan scaffold pun berkembang, mulai dari bahan sintetis sampai alami, dari autograft, sampai xenograft. Di Indonesia, scaffold sintetik yang diproduksi dalam negeri dan juga scaffold natural untuk tulang rawan belum ada. Penelitian mengenai scaffold yang telah dilakukan sebelumnya, baru pada tahap penelitian binatang coba dan dilaporkan menimbulkan suatu reaksi inflamasi lokal. Dengan adanya teknik deselularisasi diharapkan komponen seluler yang dikenal sebagai "gal epitope" yang dapat menimbulkan respon imun dan inflamasi terhadap scaffold biologis dapat dihilangkan. ${ }^{4,5}$

Penelitian mengenai teknik deselularisasi beragam dengan hasil yang beragam serta belum adanya protokol teknik deselularisasi yang optimal untuk dipergunakan pada cartilage bovine scaffold. Dalam penelitian ini kami berusaha menemukan scaffold yang lebih optimal dengan teknik deselularisasi dibandingkan scaffold 
tulang rawan sebelumnya yakni FDBC (Freeze Dried Bovine Cartilage Powder) sehingga dapat bermanfaat untuk penyediaan kebutuhan scaffold yang bisa digunakan dalam tissue engineering pada articular cartilage defect. Bahan dasar scaffold yang berasal dari cartilage bovine dipilih karena relatif mudah diperoleh dan memungkinkan untuk diproduksi secara lokal sehingga bisa secara luas dipergunakan, sarta terjangkau untuk masyarakat Indonesia, tetapi dengan hasil yang optimal. Diharapkan dari penelitian ini bisa memberikan teknik penyediaan scaffold yang lebih baik untuk rekayasa jaringan berbasis stem cell dalam pengobatan defek tulang rawan sendi. ${ }^{6-8}$

\section{METODOLOGI PENELITIAN}

Penelitian ini dilakukan dengan menggunakan rancangan penelitian experimental study pre-post control group design pada bovine cartilage scaffold yang dilakukan proses deselularisasi. Tujuan dari penelitian ini adalah untuk mengetahui apakah teknik deselularisasi tertentu pada bovine cartilage scaffold dapat mempertahankan kadar kolagen tipe II sekaligus tetap memiliki porositas sehingga dapat digunakan pada teknik penggantian jaringan di masa depan.
Unit penelitian pada penelitian ini adalah tulang rawan sendi lutut hewan coba sapi jenis ongole berumur minimal 24 bulan yang disediakan oleh Rumah Pemotongan Hewan Pegirian (RPH Pegirikan) Surabaya yang telah bersertifikat bahwa sapi yang disediakan adalah sapi sehat dan sesuai dengan kriteria inklusi penelitian, kemudian diolah oleh Bank Jaringan RSUD Dr. Soetomo Surabaya dan dijadikan unit sample penelitian.

Cartilage yang telah dilepas dari tulang rawan sendi lutut sapi dengan potongan silinder diameter $1 \mathrm{~cm}$, kemudian dicuci bersih, dan dibekukan di freezer dengan suhu $-80^{\circ} \mathrm{C}$. Setelah beku dilakukan pengeringan dengan mesin freeze dryer selama 2x24 jam. Kemudian dilanjutkan dengan sterilisasi radiasi sinar Gamma sekaligus untuk menurunkan sifat antigennya.

Sampel yang digunakan sebanyak 96 buah cartilage bovine scaffold yang didapat dari rumus Steel and Torrie. Sebanyak 16 buah kelompok kontrol dan 80 buah kelompok perlakuan yang akan mengalami proses deselularisaasi. Sebanyak 40 buah dengan konsentrasi SDS 2\% dan 40 buah dengan konsentrasi SDS 5\%. Kemudian masing-masing konsentrasi SDS dibagi lagi menjadi 5 kelompok berdasarkan 
http://journal.unair.ac.id/ORTHO@journal-orthopaedi-and-traumatology-surabaya-media-104.html

variasi waktu (1 jam, 2 jam, 24 jam, 48 jam, 72 jam), masing-masing sebanyak 8 buah cartilage bovine scaffold.

Selanjutnya dilakukan proses deselularisasi menggunakan teknik physical, kimiawi, dan enzimatik. Tulang rawan sendi lutut hewan coba sapi yang telah dipotong dan disterilkan, kemudian dicuci dengan Phosphate Buffered Saline (PBS) kemudian dibekukan dalam suhu $-4^{\circ} \mathrm{C}$ sebagai langkah awal tahap physical dari proses deselularisasi. Spesimen tersebut kemudian dicairkan pada suhu ruangan dan diulang dicuci menggunakan PBS. Setelah itu, spesimen tersebut direndam dalam nitrogen cair selama 2 menit, dicairkan (freeze thaw) dalam air destilasi dan dipindahkan dalam larutan PBS pada suhu ruangan selama 10 menit. Langkah akhir tersebut diulang sebanyak 5 kali. $^{9-11}$

Dalam tahap kimiawi dari proses deselularisasi, spesimen diberikan konsentrasi yang berbeda ( $2 \%$ dan $5 \%$ ) dalam sodium dodecyl sulfate (SDS) selama 1 jam, 2 jam, 24 jam, 48 jam, 72 jam dalam suhu $37^{\circ} \mathrm{C}$ kemudian diadukaduk secara perlahan. ${ }^{12,13}$
Tahap selanjutnya, segmen cartilage dicuci selama $3 \times 10$ menit dalam PBS pada suhu ruangan sambil diaduk perlahan. Kemudian dilakukan inkubasi dalam $50 \mathrm{U} / \mathrm{ml}(0,5 \mathrm{mg} / \mathrm{ml})$ DNAse dan $1 \mathrm{U} / \mathrm{ml}(50 \mu \mathrm{g} / \mathrm{ml}$ RNAse $)$. Untuk menghilangkan SDS, serta menghilangkan sisa air dari spesimen, kemudian cartilage ditempatkan pada cawan steril, dicuci dengan $75 \%$ ethanol, air destilasi steril dan PBS secara berturut-turut. $^{12,14}$

Terakhir dilakukan pengukuran variabel pada cartilage bovine scaffold kontrol dan perlakuan. Variabel kadar kolagen tipe II dengan menggunakan metode imunohistokimia yang dinilai secara semi kuantitatif menurut metode Remmele yang sudah dimodifikasi, dimana Indeks skala Remmele (Immuno Reactive Score/IRS) merupakan hasil perkalian antara skor persentase sel immunoreaktif dengan skor intensitas warna pada sel immunoreaktif. Sedangkan variabel ukuran porositasnya dengan menggunakan mikroskop elektron. 


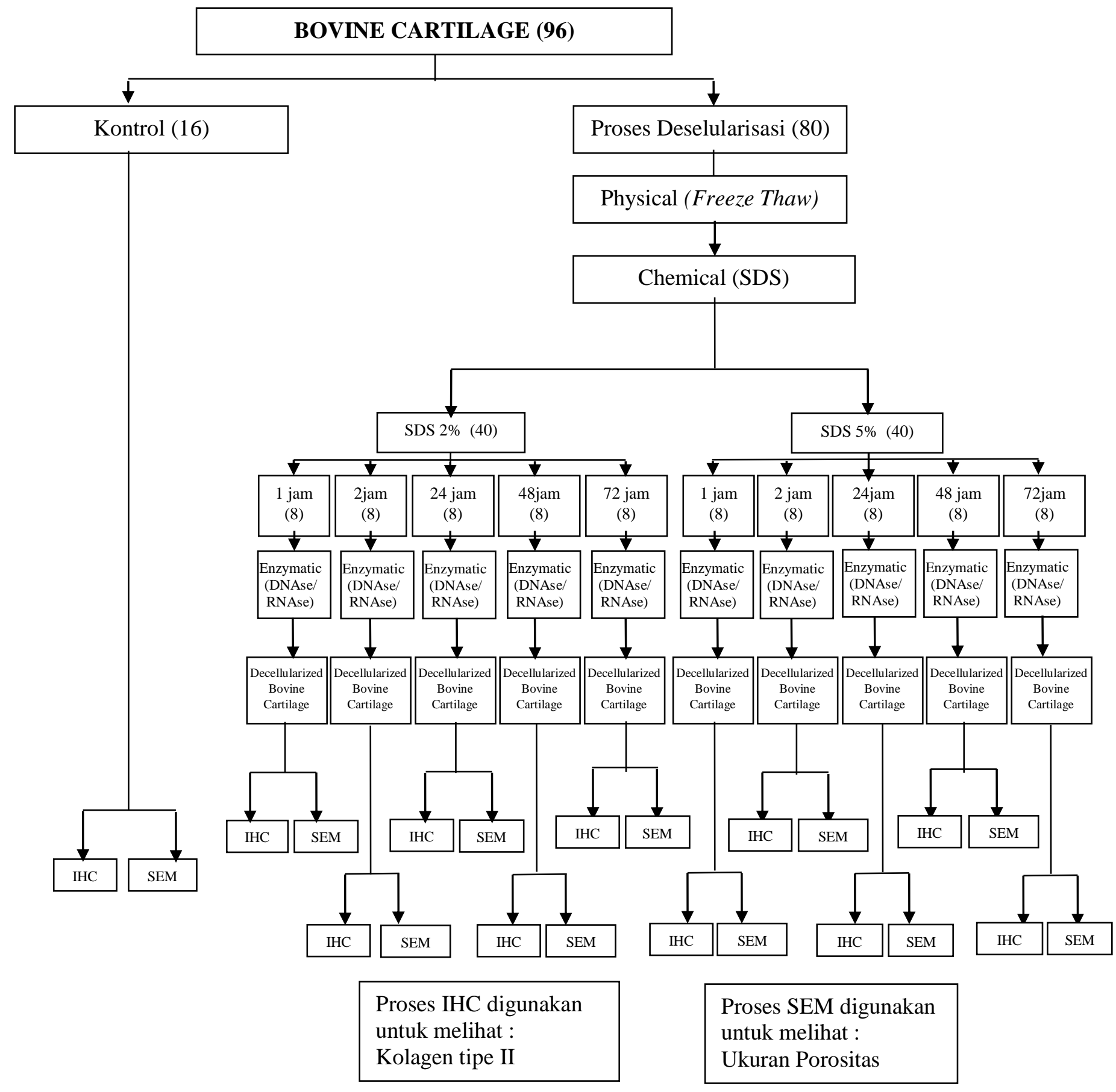

Gambar 1. Skema Alur Penelitian

\section{HASIL DAN PEMBAHASAN}

Dengan

pengecatan

imunohistokimia, tampak jelas perbedaan ekspresi kolagen tipe II dengan sel di sekitarnya sebagaimana yang terlihat pada Gambar 2. Ekspresi kolagen tipe II yang terbentuk selanjutnya dihitung pada 5 lapang pandang dengan mikroskop cahaya 
Artikel Penelitian

Vol 7 No. 1, April 2018

ISSN 2460-8742

http://journal.unair.ac.id/ORTHO@journal-orthopaedi-and-traumatology-surabaya-media-104.html

perbesaran 400X. Dari uji homogenitas

didapatkan seluruh kelompok data

terdistribusi normal $(\mathrm{p}>0,5)$. Pada uji
ANOVA diketahui bahwa terdapat kadar kolagen tipe II yang signifikan pada kelompok perlakuan $(\mathrm{P}<0,05)$.

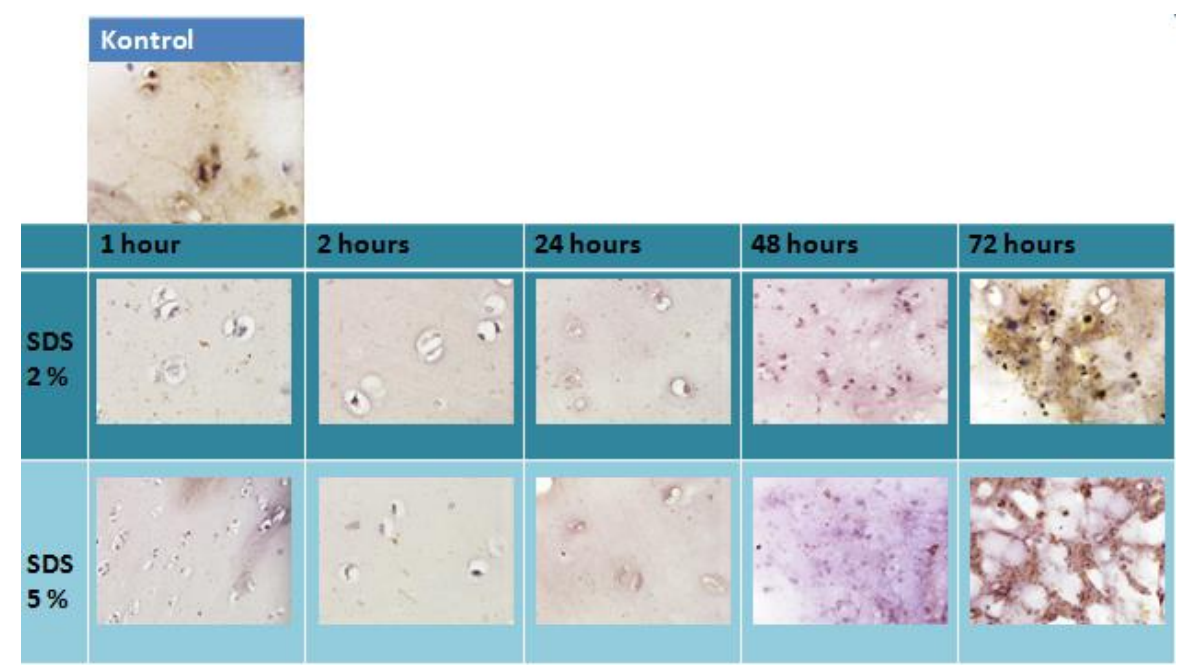

Gambar 2. Ekspresi Kolagen Tipe II dengan Perbesaran 400X

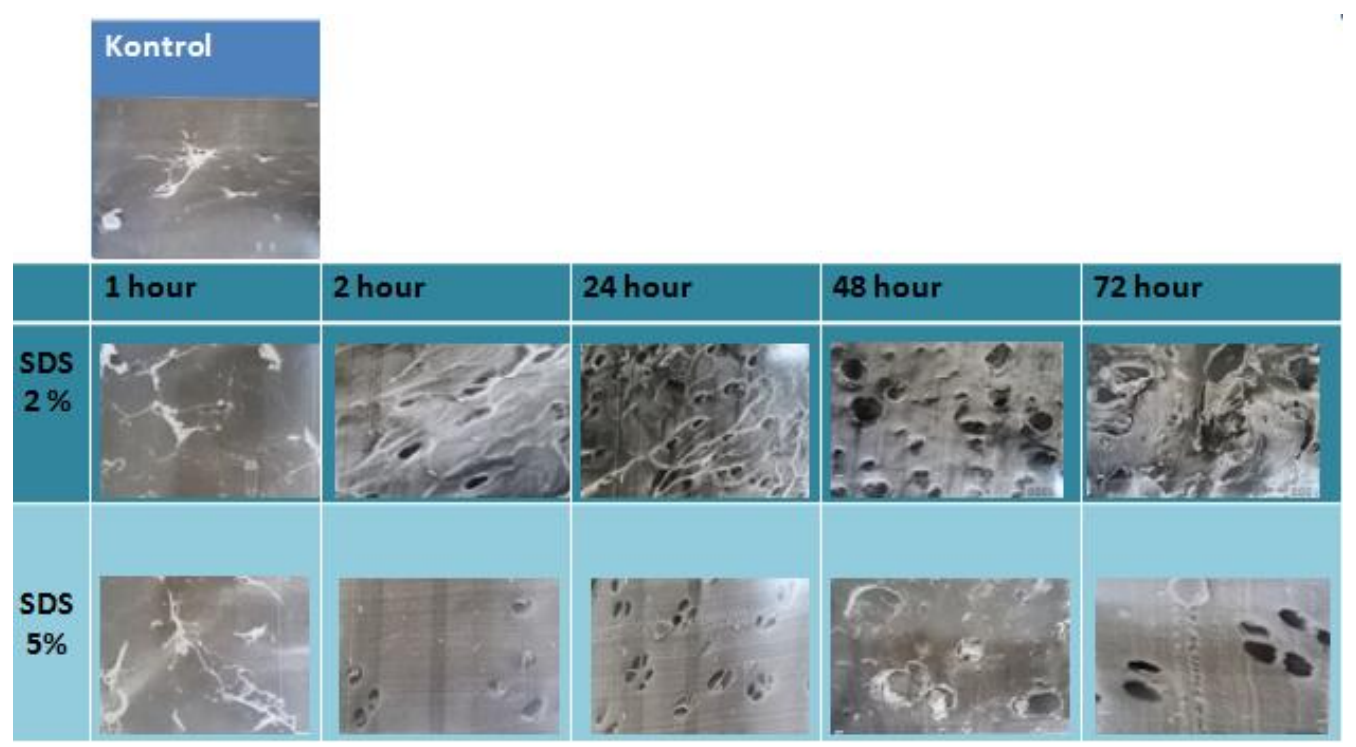

Gambar 3. Kondisi cartilage bovine scaffold di bawah mikroskop sebelum dan setelah proses deselularisasi

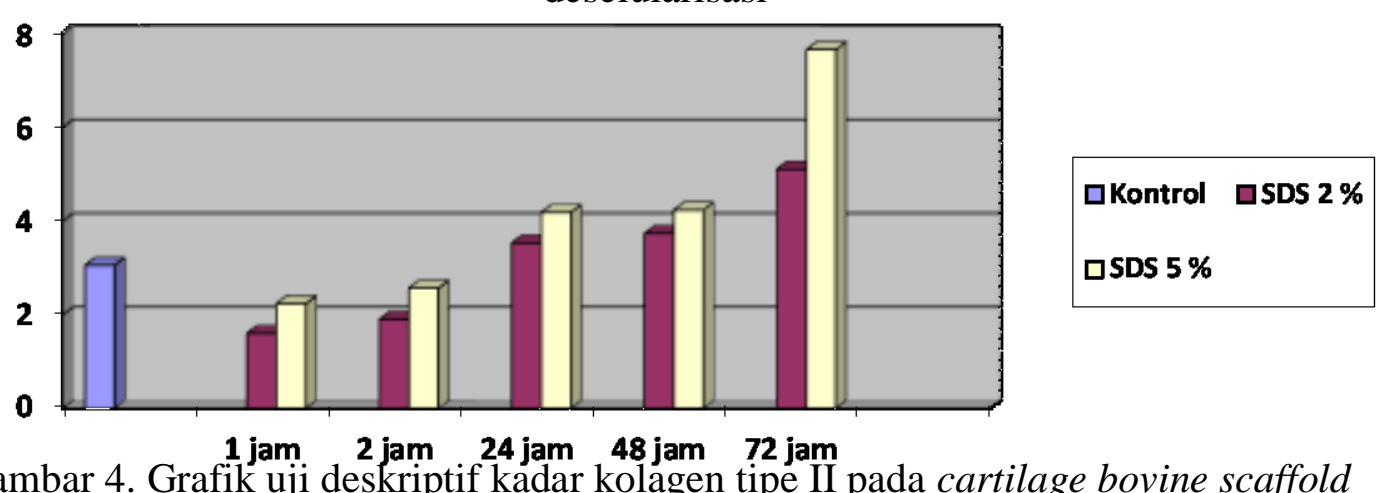

Gambar 4. Grafik uji deskriptif kadar kolagen tipe II pada cartilage bovine scaffold 47 


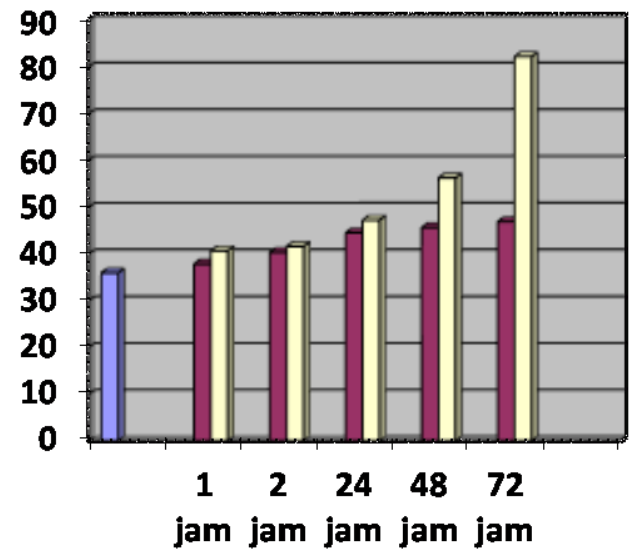

$\square$ Kontrol

$\square$ SDS $2 \%$

$\square$ SDS $5 \%$

Gambar 5. Grafik uji deskriptif porositas (luas) pada cartilage bovine scaffold

Dengan menggunakan mikroskop elektron menunjukkan diameter cartilage bovine scaffold setelah proses deselularisasi. Pada pemeriksaan mikroskop elektron terlihat hanya pada perlakuan SDS 5\% 72 jam saja yang sudah tidak didapatkan inti sel, hal ini dapat diartikan bahwa pada perlakuan SDS 5\% 72 jam, cartilage bovine scaffold terdeselularisasi secara sempurna. Dari uji homogenitas didapatkan kelompok data terdistribusi normal. Ini karena semua kelompok data didapatkan $p>0,05$. Pada uji ANOVA didapatkan $\mathrm{p}=0,0001$. Karena $\mathrm{p}<0,05$ maka terdapat perbedaan antara beberapa kelompok data. Untuk mengetahui kelompok yang berbeda maka dilakukan uji post hoc dengan hasil didapatkan terdapat perbedaan bermakna ukuran porositas pada semua kelompok SDS 5\% 48 jam dan SDS 5\% 72 jam dibandingkan kelompok lainnya.
Terjadi peningkatan kadar kolagen tipe II pada sediaan cartilage bovine scaffold yang terdeselularisasi pada 24 jam, 48 jam dan 72 jam baik pada konsentrasi SDS 2\% maupun SDS 5\% dibandingkan kelompok kontrol. Fenomena ini secara teori dapat dijelaskan karena terjadi normalisasi dari jumlah kolagen tipe II terhadap berat sebelum dilakukan proses deselularisasi, karena berat sebelum dilakukan deselularisasi menjadi berkurang setelah proses deselularisasi, sementara berat kolagen tidak terpengaruh. Di samping itu, jumlah glikosaminoglikan (GAG) juga berkurang karena proses deselularisasi, yang memberikan kontribusi terhadap jumlah kolagen tipe II secara keseluruhan meningkat. Sedangkan pemaparan waktu yang cukup singkat yakni 1 jam dan 2 jam pada SDS 2\% dan 5\% keduanya menghasilkan kadar kolagen dengan 
http://journal.unair.ac.id/ORTHO@journal-orthopaedi-and-traumatology-surabaya-media-104.html

jumlah yang sedikit menurun dibandingkan kontrol.

Bovine merupakan hewan ternak yang cukup mudah didapatkan di Indonesia, tingginya konsumsi daging sapi di masyarakat kita dipenuhi dengan kurang lebih 3 juta ekor sapi per tahun. ${ }^{11}$ Bovine articular cartilage juga memiliki komponen morphogenic factor yang disebut cartilage derived morphogenic proteins(CDMP), sehingga kita juga akan mendapatkan keuntungan material lain dari kandungan komponen matriks ekstraseluler tulang rawan sendi yang berasal dari bovine articular cartilage ini berupa kolagen tipe II serta komponen matriks ekstraseluler lain di dalamnya. ${ }^{15,16}$

Scaffold merupakan kerangka awal yang bersifat temporer sebagai media perlekatan dari stem cell, seiring berjalannya proses proliferasi dan diferensiasi stem cell akan mensintesa matriks baru. Dalam proses ini scaffold bukan hanya berperan sebagai mechanical cues namun juga merupakan biochemical cues yang menjadi cetakan terhadap matriks baru yang akan dihasilkan oleh stem cell. Hal Ini juga merupakan salah satu dasar keunggulan dari natural scaffold dibandingkan syntethic scaffold, dimana natural scaffold akan memiliki peran tambahan dalam segi biochemical cues dibandingkan syntethic scaffold yang memiliki peran dominan dalam konstruksi mekaniknya saja. ${ }^{17-19}$

Penggunaan scaffold yang berasal dari bovine articular cartilage pada penelitian ini ditujukan selain untuk memberikan kerangka mekanik juga menjadi microenvironment bagi stem cell. Kandungan matriks ekstraseluler bovine articular cartilage berupa kolagen tipe II diharapkan masih memiliki kadar yang cukup tinggi sehingga fungsi sebagai biochemical cues masih cukup optimal. ${ }^{20}$

Pada penelitian ini, proses deselularisasi yang dilakukan menggunakan kombinasi dari perlakuan fisik, kimiawi dan enzimatik karena memandang kompaknya struktur dari cartilage dan rendahnya kemampuan penetrasi dari larutan. Pada tahap fisik, bovine cartilage dicuci dengan larutan PBS dan ditempatkan pada suhu $-4^{\circ} \mathrm{C}$ untuk menimbulkan pembentukan dari kristal es yang nantinya dapat mengganggu kondrosit dan menyebabkan lisisnya sel. Setelah itu, bahan dipaparkan pada proses pembekuan menggunakan nitrogen cair yang dapat menyebabkan kerusakan membran lebih jauh dan menghilangkan protein. Proses fisik ini merusak sel 
namun tidak serta merta menghilangkan fragmen-fragmennya. ${ }^{21-23}$

Tahap selanjutnya yaitu tahap kimiawi, kami menggunakan cairan SDS yang dapat berinteraksi dengan membran sel termasuk plasma dan membran nuklear serta melisiskan mereka namun disisi lain dapat mengganggu protein dengan cara melipat kembali molekulmolekulnya. Khusus pada tahap kimiawi, kami melakukan beberapa perlakuan yang berbeda. Pada penelitian ini, kami menggunakan 2 macam konsentrasi yaitu cairan SDS 2\% dan 5\% serta tenggat waktu perendaman yang berbeda. Namun dari penelitian yang kami lakukan, hanya dengan menggunakan SDS 5\% selama 72 jam, yang dapat menghilangkan sel dari bovine cartilage secara total. Setelah tahap kimiawi, bovine cartilage mengalami tahap enzimatik dengan DNAse/RNAse untuk menghindari penularan penyakit, mengurangi inflamasi dan respon imun terhadap scaffold dan mengurangi risiko penolakan setelah implantasi, terutama dengan jaringan donor xenogenic atau alogenic. $^{22}$

Setelah itu bahan kembali dicuci menggunakan PBS untuk kemudian dilakukan pemeriksaan IHC dan SEM. Seperti ditampilkan di rangkaian gambar konsentrasi SDS yang lebih kecil dan waktu yang lebih singkat tidak dapat menghilangkan sel dari bovine cartilage secara sempurna. Pada preparat yang direndam SDS 5\% selama 72 jam, proses deselularisasi terjadi secara sempurna, meskipun demikian dari pewarnaan IHC (pada akhir proses deselularisasi) tampak ditemukan adanya kandungan kolagen tipe II dengan kadar yang signifikan lebih tinggi dibandingkan dengan kontrol (bovine cartilage tanpa proses deselularisasi), hal ini dimungkinkan karena menurunnya kandungan air setelah mengalami proses deselularisasi secara fisikal. Tidak hanya itu, bila dibandingkan dengan preparat yang lainnya, tetap kadar kolagen tipe II lebih tinggi pada preparat yang terdeselularisasi sempurna. ${ }^{24}$

Ukuran scaffold juga merupakan variabel yang cukup penting. Apabila ukuran pori yang terbentuk terlalu kecil akan menyebabkan terganggunya migrasi sel, terhambatnya proses difusi nutrisi dan pembuangan bahan metabolism dari sel. Demikian pula sebaliknya apabila ukurannya terlalu besar akan mengurangi luas permukaan yang tersedia untuk perlekatan stem cell pada scaffold..$^{25}$

Diameter pori scaffold optimal yang berkisar antara $85 \mu \mathrm{m}-325 \mu \mathrm{m}$ akan 
memfasilitasi terjadinya attachment pada fase awal sekaligus memungkinkan untuk terjadinya difusi nutrisi dan pembuangan hasil metabolisme sel. Rentang diameter scaffold yang berkisar antara $100 \mu \mathrm{m}-300 \mu \mathrm{m}$ akan memberikan lingkungan yang optimal untuk terjadinya proliferasi sel dengan tetap memiliki peran untuk melakukan retensi terhadap matriks ekstraseluler yang diproduksi oleh sel. Faktor lain yang tidak kalah penting adalah bagaimana scaffold yang dibuat bisa memadukan fungsi sebagai kerangka mekanik yang cukup kokoh namun tetap bisa memberikan ruang untuk terjadinya transportasi elemen biologis bisa berjalan dengan baik di dalamnya. ${ }^{24,25}$

Konstruksi scaffold yang terlalu "stiff" juga kurang menguntungkan karena akan membatasi kecepatan migrasi sel untuk membentuk jaringan yang baru. Rancang bangun scaffold hendaknya cukup memberikan ruang sehingga chondrocyte yang memiliki ukuran $9 \mu \mathrm{m}-10 \mu \mathrm{m}$ bisa bergerak secara bebas, termasuk juga harus tersedia ruang yang cukup untuk deposisi matriks baru yang dihasilkan oleh chondrocyte tersebut, apabila semua persyaratan tersebut dipenuhi maka integrasi jaringan yang baru bisa dicapai lebih cepat. $^{25}$
Dari pemeriksaan SEM pada preparat cartilage bovine scaffold yang terdeselularisasi sempurna (SDS 5\% 72 jam) didapatkan memiliki porositas yang saling berhubungan dalam jumlah besar sehingga memungkinkan infiltrasi dan penempelan sel. Ukuran diameter pori yang ditemukan dalam penelitian kami pada decellularized bovine cartilage sebesar $200 \mu \mathrm{m}$, merupakan ukuran yang ideal untuk terbentuknya scaffold yang dapat memberikan ruang bagi stem cell dan memungkinkan adanya transport materi elemen biologis. ${ }^{24,25}$

\section{KESIMPULAN}

Kesimpulan:

1. Decellularized cartilage bovine scaffold sebagai formula scaffold mesenchymal stem cell didapatkan mengandung komponen matriks ekstraseluler, yang dibuktikan dengan didapatkannya komponen kolagen tipe II didalamnya serta memiliki porositas yang saling berhubungan dalam jumlah besar sehingga memungkinkan infiltrasi dan penempelan sel..

2. Kadar kolagen tipe II pada decellularized cartilage bovine scaffold mengalami peningkatan yang signifikan pada perlakuan SDS 5\%, 72 jam dibandingkan dengan 
Artikel Penelitian

Vol 7 No. 1, April 2018

ISSN 2460-8742

http://journal.unair.ac.id/ORTHO@journal-orthopaedi-and-traumatology-surabaya-media-104.html

kontrol fresh bovine cartilage, serta perlakuan lainnya. Hal ini bisa terjadi karena normalisasi dari jumlah kolagen tipe II terhadap berat sebelum dilakukan deselularisasi.

3. Porositas pada decellularized cartilage bovine scaffold mengalami peningkatan yang signifikan pada perlakuan SDS 5\%, 72 jam dibandingkan dengan kontrol fresh bovine cartilage, serta perlakuan lainnya.

\section{REFERENSI}

1. Heriawan R. Perkembangan Indikator Utama Sosial Ekonomi Indonesia. Subdirektorat Layanan dan Promosi Statistik Badan Pusat Statistik Indonesia. Jakarta: ISSN. 2011; 2085.5664.

2. Claire V, Carine Bouffi, Christophe Merceron, Jan Gordeladze, JeanMarc Brondello, Christian Jorgensen ,Pierre Weiss, Jérome Guicheux, Danièle Noël; Cartilage Tissue Engineering: Towards a BiomaterialAssisted Mesenchymal Stem Cell Therapy; Current Stem Cell Research \&Therapy. Hospital Lapeyronie, Montpellier, Bentham Science Publishers Ltd, France. 2009; 318332.

3. Myron Spector; Biomaterials-Based Tissue Engineering And Regenerative Medicine Solutions To Musculoskeletal Problems Tissue Engineering, Boston Healthcare System, And Orthopaedic Research
Laboratory, Harvard Medical School, Boston,USA,Swiss Med Wkly. 2006;136:293-301.

4. Dwikora, Sasetia DR, Taufik A, Rofi'i, Sadabaskara, Bembie R, Musbhida A and Adi G. Freeze dried bovine cartilage powder as an alternative scaffold for cartilage defect. International symposia of stem cell and Tissue bank. Surabaya. 2011.

5. Asheesh Bedi, Brian T. Feeley, Riley J. Williams, Management of Articular Cartilage Defects ofthe Knee; Journal of Boneand Joint Surgery, Am. 2010; 92:9941009./JBJS.I.00895

6. M.Wessling D.Stamatialis, K. Boller, C.A.van Blitterswijk, D.W. Grijpma; Design Strategies for Tissue Engineering Scaffolds. Bernke Papenburg, Enschede, The Netherlands. 2009.

7. Ferdiansyah. Use of Freeze-Dried Irradiated Bones in Orthopaedic Surgery.In Radiation in Tissue Banking Basic Science and Clinical Applications of Radiated Tissue Allografts (edited by Nather A, Yusof N, Hilmy N). World Scientific, Singapore. 2007; 317326.

8. Konakci KZ, Bohle B, Blumer R, Hoetzenecker W, Roth G, Moser B, et al. Alpha-Gal on bioprostheses: xenograft immune response in cardiac surgery. Eur J Clin Invest 2005;35:17-23.

9. Badylak SF, Taylor D, Uygun K. Whole-organ tissue engineering: decellularization and recellularization of three- 
dimensional matrix scaffolds. Annu

Rev Biomed Eng 2011;13:27-53.

10. Salter MB. Textbook of Disorders and Injuries of the Musculoskleletal System. $2^{\text {nd }}$ ed.1983 p.6-25

11. Scott J. Hollister ; Porous scaffold design for tissue engineering Is At The Scaffold Tissue Engineering Group, Departments Of Biomedical Engineering, Surgery and Mechnical Engineering, The University of Michigan, Ann Arbor, Michigan 41809, USA

12. Baltimore.Tissue Engeneering, Journal of Bone and Joint Surgery. 2005; 86 : 1541-1557.

13. Cook SD, Barrack RL, Skinner HB. Basic Science in Orthopaedic Surgery, In : Skinner HB, ed. Current Diagnosis and Treatment in Orthopaedics. $2^{\text {nd }}$ ed. New York : Lange Medical Book. 2000; p. 8 11.

14. Akeson WH, Amiel D, Gershuni DH. Articular Cartilage Physiology and Metabolism. In: Resnick D, ed. Diagnosis of Bone and Joint Disorders. $3^{\text {rd }}$ ed. Philadelphia: Saunders WB.1996; p.769 - 90.

15. Vunjak-Novakovic G. The fundamentals of tissue engineering: scaffolds and bioreactors. In: Tissue Engineering of Cartilage and Bone (Novartis Foundation Symposium). Editors: Bock G and Goode J. John Wiley \& Sons Ltd, Chichester. 2003; 249, 34-51.

16. Erdag G,Morgan JR. Allogeneic versus xenogeneic immune reaction to bioengineered skin grafts.Cell Transplant.2004; 13:701-12.

17. Gock H, Murray-Segal L, Salvaris E, Cowan P, D'Apice AJ.
Allogeneic sensitization is more effective than xenogeneic sensitization in eliciting Galmediated skin graft rejection. Transplantation. 2004; 77:751-53.

18. Ross JR, Kirk AD, Ibrahim SE, Howell DN, Baldwin WM 3rd, Sanfilippo FP. Characterization of human anti-porcine "natural antibodies" recovered from ex vivo perfused hearts - predominance of IgM and IgG2. Transplantation.1993. 55:1144-50.

19. BernardMP, ChuML, Myers JC, Ramirez F,Eikenberry EF, Prockop DJ. Nucleotide sequences of complementary deoxyribonucleic acids for the pro alpha 1 chain of human type I procollagen. Statistical evaluation of structures that are conserved during evolution. Biochemistry 22. 1983; :5213-23.

20. Bernard MP, Myers JC, Chu ML, Ramirez F, Eikenberry EF, Prockop DJ. Structure of a cDNA for the pro alpha 2 chain of human type I procollagen. Comparison with chick cDNA for pro alpha 2(I) identifies structurally conserved features of the protein and the gene. Biochemistry 22.1983;1139-45.

21. Constantinou CD, Jimenez SA. Structure of cDNAs encoding the triple-helical domain of murine alpha 2 (VI) collagen chain and comparison to human and chick homologues. Use of polymerase chain reaction and partially degenerate oligonucleotide for generation of novel cDNA clones. Matrix.1991;11:1-9.

22. Exposito JY, D'AlessioM, Solursh M, Ramirez F. Sea urchin collagen 
evolutionarily homologous to vertebrate pro-alpha 2(I) collagen. $J$. Biol. Chem. 1992;267:15559-62.

23. McPherson TB, Liang H, Record RD, Badylak SF. Galalpha(1,3)Gal epitope in porcine small intestinal submucosa. Tissue Eng.2000;6:23339.

24. Raeder RH, Badylak SF, Sheehan C, Kallakury B, Metzger DW. Natural anti-galactose alpha1,3 galactose antibodies delay, but do not prevent the acceptance of extracellular matrix xenografts. Transplant.Immunol.2002;10:15-24. 25. Daly K, Stewart-Akers A, Hara H, Ezzelarab M, Long C, et al. Effect of the alphaGal epitope on the response to small intestinal submucosa extracellular matrix in a nonhuman primate model. Tissue Eng. Part A 2009;15:3877-88. 